\title{
Analysis on the Reform and Innovation of Physical Education Based on the Status Quo of College Physical Education
}

\author{
Guo Hui
}

(Central South University of Forestry and Technology, Changsha, 410004)

Keywords: Physical Education; Status Quo; Teaching Reform; Innovation

\begin{abstract}
With the rapid development of China's economy and continuous social progress, the reform of China's education system has been further deepened, and the reform of college physical education has also entered a new era of innovation. It's known to all that college physical education is the most pivotal period of lifelong sports, and the current college physical education has many negative drawbacks: outdated teaching contents, unreasonable evaluation system of achievements and neglecting of the development of physical education while only focusing on imparting theoretical knowledge. This article aims at the problems existing in the college physical education in China, trying to put forward some suggestions for the objectives of physical education, the setting of physical education curriculum, teaching contents and evaluation mechanism. To conclude, this paper expects to explore the direction of the development of college physical education so as to seek for a new model of physical education that will enable students to enjoy lifelong exercises. In order to explore the direction of the development of university sports teaching reform, we will seek for a new model of physical education that will enable students to enjoy lifelong and exercise for life.
\end{abstract}

\section{Introduction}

In recent years, with the reform of higher education entering the ranks of global education, physical education as an important part of it has been continuously deepened and reformed. However, so far, although the overall level of college physical education in our country has improved a lot, it is still somewhat lagged behind and it is still far behind European and American universities. Nowadays, the term 'quality education' has frequently appeared in major education and teaching fields, and college physical education is no exception. In addition, there is a deterioration in structural well-being. In order to improve the quality of teaching and the physical quality of students, made contemporary college students better able to adapt to the new and different developments of contemporary society, people have to face and embrace current problems and carry out reforms and innovations. This article explores and analyzes a glittering array of shortcomings of the status quo of physical education in colleges, and proposes corresponding and reasonable solutions to promote its reform and innovation.

\section{The Role of College Physical Education in Students' Education}

\section{Improve Student Physique}

The role of college physical education in enhancing the physical fitness of students is self-evident. It can also cultivate students' awareness, interest, habits and abilities of life-long sports. After entering into the society, students will not only have a healthy body, but also have sports literacy and it will be easier for them to adapt to modern production and lifestyle as well as improve the quality of life.

\section{Promote the Development of Students' Intelligence}

Sports can promote human brain development, regulate the central nervous system of the brain, improve its function, and lay a good material foundation for people to engage in intellectual activities. It can also directly promote the development of intelligence such as observation, memory, imagination and thinking. 


\section{Cultivate Students' To Be Tenacious}

In physical education training and competitions, students must give their best efforts to overcome physical and psychological difficulties or obstacles one after an other, and they must always exert great will to work hard. Therefore, the physical education process can effectively train students' tenacious will quality. In addition, a variety of competition activities enable students to obtain diverse strong emotional experiences, thereby cultivating their own sense of responsibility and mutual trust, mutual help, solidarity, cooperation, and helping people to enjoy the spirit of their own, improve their own appreciation, creativity and expressiveness.

\section{Status Quo of Contemporary Physical Education in Colleges}

\section{Old Teaching Concepts of College Physical Education}

The traditional concept of physical education has been unable to meet the growing needs of students for physical education and exercise. The main reason is that the concept of physical education is rather obsolete and there are problems in the concept of physical education teaching, curriculum setting, teaching methods and teaching organization. What's more, the teaching materials are relatively old in content and there is no way to improve the overall quality of students. In particular, the obsolete concept of sports leads to the difficulty in cultivating the goal of the concept of lifelong sports for the students in teaching, which is a problem that needs to be improved. Therefore, Chinese college physical teaching should change the traditional teaching methods and adopt different teaching methods according to different training objectives so as to improve the concept of physical education .

\section{Backward Teaching Mode}

When entered into the 21st century, our country has introduced advanced theories and information of Western countries in college teaching. However, they barely scratched the surface and there is no obvious change in teaching structure. When explaining the sports, teacher often use demonstration method and competition method, and teach according to the teaching materials, which results in students' losing interest in learning. In addition, the teaching mode is teacher-centered and crammed while the entire teaching mode is relatively rigid and does not focus on enhancing student's physical fitness. There are a great deal of reasons contributing to this teaching mode, mostly because of traditional teaching concepts and actual physical education to some extent. The result of using the traditional teaching model is that students' main role cannot be fully exerted. In teaching, teachers neglect students' learning methods, overemphasized students' mastery of sports action techniques. They only pay attention to technology and ignore the theory. Teachers mostly consider about the common problems of students, but ignore the students' individual qualities. Thus, the traditional teaching methods are not conducive to students' enthusiasm for learning and hampered the overall development of students.

\section{Unreasonable Curriculum Setting}

The syllabus used in college physical education has always been highlighting social values while negelecting the personality of individuals. Moreover, college physical education is single and relys too much on standard teaching materials, which does not aim to cultivate talents. Furthermore, its teaching form and curriculum is single, teaching content is obselete, resulting in standardized process, hampering the thinking of college PE teachers and preventing students from participating in sports. Although some emerging sports programs are now incorporated into sports textbooks, due to the current shortage of teachers for physical education and the number of courses that can be offered, physical education classes generally remain on ball, track and field, and aerobics projects. In the past, most of the students were exposed to these projects from an early age, which made it easy for students to lose interest in learning and to reduce students' emphasis on physical education. It is difficult to stimulate students' interest in learning sports. As a result, college students cannot recognize the physical education teaching model, which affects the quality of physical education. 


\section{Provide Solutions and Countermeasures for the Existing Problems in College Physical Education}

\section{On the Basis of Modern Curriculum Theory}

The modern curriculum theory is a guide for physical education and promotes equal opportunities. That is, every student can gain a chance to show his or her own opportunities in physical education. It emphasizes the students' choice of learning autonomy, choosing within a certain range that they are interested in and willing to try. In addition to emphasizing that physical health enhances students' physical fitness, modern curriculum theory also pays more attention to moral education and cooperation spirit and students' individual creative ability plays a very critical role in modern sports teaching.

\section{Diversification of Teaching Methods and Contents}

New types of physical education teaching methods require teachers to provide personalized and individualized teaching services. From the teaching method of "teaching students to learn", teachers need to be student-centered, teach them how to find fun in physical education, and explore the mysteries of the learning process. And to promote divergent thinking, to provide students with the process of exploring and thinking about themselves, and to pay attention to the changes in each student's different psychological processes. Through such a teaching process, students can independently solve the problems encountered, and actively ask reasonable questions, help to improve the interest and stimulate enthusiasm for learning, so that students learn in it, enjoy it.

Optimize curriculum settings, eliminate duplicate teaching sections and integrate modern multimedia teaching modes into physical education. Teachers should not only base themselves on textbooks, but also increase the interest and practicality of the textbook through more methods, trying their unremitting efforts to develop teaching models and content that can improve the efficiency of physical education and fun, paying attention to the differences among students at the same time, making teaching methods meet both the modern educational laws and the psychological demands of students. Therefore, it will be definitely conducive to improving teaching effectiveness and inspire students' initiative in learning.

\section{Transform the Concept of Teachers and Become People-Oriented}

Nowadays, many P.E. teachers do not have a clear understanding of their position and role in teaching. They also fail to achieve the people-oriented principle and neglect to cultivate students' sports literacy in physical education. Only simple action decomposition and repetition will complete the physical education class. Therefore, in the actual teaching process under the reform and innovation, teachers are required to do a clear role in guiding their own teaching. At the same time, they must also pay attention to the reflection of the student's learning status, so as to improve each student's ability to learn physical education and find students' learning potential and igniting students' learning motivation.

\section{Conclusion}

College physical education reform and innovation is a permanent them as reform and innovation are a resolute revolution. It is necessary to break the traditional education and teaching system, change the traditional teaching concepts, change the traditional teaching models and methods, and improve the new teaching content as well as the new institutional structure in order to adapt to the needs of the new times. College physical education is the last stage of college sports, so we must re-examine their own characteristics, and constantly deepen its reform to adapt to the changing society, and establish an education and teaching system that can adapt to modern society. How to allow students to increase their awareness of physical exercise while learning professional knowledge and to improve their physical fitness is the ultimate goal of sports reform and innovation.

\section{References}

[1] Yuan G. A "Three Self - decisions" Course Selection System and a Study of Practice of Physical 
Education Reform of Higher Education[J]. Journal of Xian Institute of Physical Education, 2005.

[2] Gao R, Zhang J H, Mao Z M. Introspection on the Reform of Physical Education and Health Curriculum in China[J]. Journal of Beijing Sport University, 2007.

[3] Hui-Qing L V. On "Three-Independence" Selected-Event System and Curriculum Reform of Physical Education[J]. Journal of Beijing Sport University, 2008.

[4] Liu Z. On the Exploration of Educational Resources and the Reform of Physical Education in College[J]. Journal of Sports \& Science, 2012.

[5] Zhang X Q. Value choices in the reform of physical education curriculum in basic education in China in the new century.[J]. Journal of Physical Education, 2013:49-53.

[6] Jiang M C, School F P. The New Period Reform of Physical Education in Our Country Middle Occupational School[J]. Journal of Hubei Correspondence University, 2016.

[7] Xiao Y, Xueyun H E, Luo Z, et al. Integrating Content and Language: A Proposal for the Reform of English Teaching in the College of Physical Education and Sports Science at Hengyang Normal University[J]. Science \& Technology, 2016.

[8] XIE Xiao-long. Research on the teaching reform of Physical Education Major[J]. Journal of Hunan City University(Natural Science), 2016.

[9] Hou G, Zhou X, He G, et al. On Theory and Practice of Comprehensive Reform of Physical Education Major[J]. Journal of Xiangnan University, 2016.

[10] Run-Ping W U. Reform of Physical Education in Colleges and Universities in the Background of Sunshine Sports[J]. Journal of Guangzhou Sport University, 2015.

[11] Zheng J. Analysis of the present situation and suggestions on the reform of physical education in Colleges and Universities[J]. Journal of Jilin Agricultural Science \& Technology University, 2017.

[12] Xue H W. Research on the Reform of Physical Education Curriculum in Colleges and Universities from the Perspective of Life Education[J]. China School Physical Education, 2017.

[13] Mao Y, Yang H, Liu Y. Exploration on the Reform of Physical Education in the Construction of City-based,Application-oriented Universities[J]. Journal of Beijing Union University, 2018.

[14] MA Xiao-chen. Research on the Reform of Physical Education in Higher Vocational Colleges Under the New Media Environment[J]. Education Modernization, 2017. 